\title{
Suppressing the Hyperactivity Behaviour of Students with Autism Through A Time-Out Strategy
}

\author{
Damri \\ Faculty of Education \\ Universitas Negeri Padang \\ Padang \\ Damrirajomdn18@gmail.com
}

\begin{abstract}
This study is an attempt to reduce the behavior of hyperactivity indicated by the behavior of always moving and pacing back and forth through a time-out strategy and procedure the tenth grade students of SLB Autism YPPA Padang. The approach used in this study was a Single Subject Research (SSR) with the design of "A-B-A". The results of the study showed that, based on the six observations and interviews (each done within at least eight minutes) as well as the intervention on five observations; it was found that the behavior of pacing back and forth performed by student $X$ decreased with the duration of 4 minutes. At the baseline condition after intervention (A2) where the observation was done four times, it was found that the behavior of pacing back and forth performed by student $X$ was getting better with the lowest duration of 2 minutes. Therefore, the researcher suggests using the strategy and procedure of timeout in reducing children's hyperactivity behavior. Besides, teachers and other researchers are suggested to apply it to other students with autism.
\end{abstract}

Keywords-strategies the hyperactivity behavior, suppressing efforts, students with autism

\section{INTRODUCTION}

Special education is an education especially provided for learners with obstacles and abnormalities or learners with exceptional intelligence, popularly known as students with special needs, held in both inclusive and exceptional schools (SLB-SDLB) at the level of elementary and secondary education. Students/Children with special needs are those who have physical, motor, intellectual, or behavioral barriers/disabilities, and one of which is autism. Autism is derived from the word auto (self) and ism (a suffix of action or a state), so autism might mean an understanding indicating disorders in communicative, social, and behavioral development [1]. Furthermore, Leo Kanner says that autism is a type of developmental disorder in children who tend to be alone in solitude and difficult to communicate and to do social interaction [2].

Autism occurs conspicuously after the children grow older because the impacts of brain tissue abnormalities that have occurred since birth complicate the provision of coaching and education services to change the behavior that has been attached. The behavior of children with autism in their social interaction is indicated by the lack of interest to play with their friends. They prefer to be alone, have little or no eye contact or avoid gazing, and tug at the hands of others to force to do what they want. In addition, they are attracted to spinning objects; therefore, when they play the toys, they do not play them according to their proper function. Moreover, they are neither creative any imaginative, and they are very attached to a particular object or toy. Furthermore, children with autism are also indicated by late or abnormal developments compared to normal children because their social, communication and cognition skills that used to develop normally will gradually decline and even disappear as they grow older.

Hyperactivity is behavior or a response characterized by high levels of activity and lack of rest. This behavior is contradictory when hyperactive children are asked to sit and remain silent for long periods of time (e.g. during the learning process in a classroom). Sunanto argues that hyperactivity is an excessive movement beyond the movement that is generally done in childhood [3]. Usually since they were babies, they have shown a lot of movements and have been difficult to calm down. Cooperation with all parties including experts, parents, communities, schools, and government needs to be established to produce expected educational objectives. Meanwhile, the hyperactive behavior of children is characterized by their less ability to focus their attention, difficulty to follow an interaction, frequent nervousness visible through frequent movements of their hands and feet, and inability to sit quietly [4]. This research was motivated by the preliminary study on $X$, the 17 years old man and the student of SLB AUTISMA YPPA Padang. The assessment on $\mathrm{X}$ carried out in his school reported that he was suffering from verbal and nonverbal communication disorders, speech disorders, behavioral disorders, emotional disorders and perception disorders. Meanwhile, he was physically normal, his weight was $60 \mathrm{~kg}$, his height was $152 \mathrm{~cm}$, and had no history of disease. $\mathrm{X}$ lived with his parents and had a younger brother. His family did understand his behaviors that were often harmful to himself and to others such as pacing back and forth, throwing objects, irritability, biting, banging heads and so forth. His family, especially his parents, also had tried to change his behavior by always watching him both at home and 
at school. At school, X always walked back and forth and was never forced to follow the lesson because he liked going in and out of classroom until he got tired. In such situation, his teacher was unable to stop his behavior and could not do anything to overcome this problem.

To explore and understand about student $\mathrm{X}$, the researcher made observations by looking at the condition of $\mathrm{X}$ when he was very tempestuous. Based on these observations, it was found that when $\mathrm{X}$ arrived at school, he immediately showed unnatural behavior by banging his head into the door's wooden frame, pacing back and forth, disturbing the comfort of other students. In addition, $\mathrm{X}$ also liked to bite. Such unnatural behavior appeared because $\mathrm{X}$ did not like being yelled at, scolded or banned in a high tone. Furthermore, X did not like to see changes in the location where a particular object is usually placed. For example, the shoes or sandals which are usually placed on the shelves should not be moved to other places because this will trigger his anger against the situation. At the time of observations, a change in locating his shoes made him rampage at school by banging his head to the door's frame until it bled. Some of the teachers in the school tried to hold him, but he resisted, wriggled and bit the hands of one of the teachers.

Based on the facts and problems elaborated in the previous paragraphs, the researcher explores the behavior of $\mathrm{X}$ by trying to suppress his hyperactivity behavior through the timeout strategy.

\section{METHOD}

In relation to the purpose of this research, i.e. to suppress hyperactivity behavior of student with autism through time-out strategy, the researcher used experimental research design to examine the event or symptom that emerged in the form of single subject research (SSR) experiment. Arikunto said that "experimental research is a research conducted to examine whether the experiment provides the effect to the subject being investigated in addition to trying to examine the presence or absence of causal relationships [5].

This research used A-B-A design consisting of baseline condition 1 (A1) in which the child's initial hyperactivity behavior of pacing back and forth was observed before the treatment was given. Condition B is an intervention condition in which the treatment/intervention was given through timeout procedure. Then the third condition was the second baseline condition (A2) in which the intervention was no longer given. The second baseline condition was intended to see the functional relationship between the free variables and bound variables, whether the intervention provided changes to the target behavior, i.e. reducing the hyperactivity behavior of pacing back and forth performed by X.

The subject of this research was identified as X, a 16 years old boy with Autism studying in SLB Autism YPPA Padang. In terms of his physical appearance, he does not have any shortcomings, but in terms of his behavior, he looks very hyperactive. The data were collected using interview and direct observations. The observations made were to see the unnatural behavior of pacing back and forth performed by $\mathrm{X}$. The interviews were conducted to his teachers and parents.
The data collection was conducted in SLB Autism YPPA Padang and in the home of the subject. Then, the results of this study were incorporated into the data collection format. The data collection tool in this research used time duration record format. In this study, the researcher directly observed the behavior of the child's hyperactivity.

The data in this research were analyzed using a visual graph analysis technique that is by plotting the data into graphs then the data were analyzed based on the components at every condition of baseline (A1), intervention (B), and baseline (A2).

\section{RESULT AND DISCUSS}

The data obtained from the single subject research were analyzed using visual analysis of graphic data. The data were obtained from the observations on condition A1 (baseline before intervention), condition $\mathrm{B}$ (intervention), and condition A2 (baseline after intervention).

At the baseline condition (A1), the data were obtained through the observations on the ability of the child to reduce his hyperactivity behavior (pacing back and forth) before being given intervention. The observations on this condition had been done for 6 days in which the time duration spent for each of the observations was 8 minutes, 15 minutes, 19 minutes, 8 minutes, 8 minutes, and 8 minutes. This means that the observations on this condition were stopped on the sixth day because the data had been considered stable.

At the intervention condition (B), the data obtained showed that the time duration spent for each of the interventions was 4 minutes, 6 minutes, 5 minutes, 5 minutes, and 5 minutes. These data proved a decrease in the duration of the child's behavior in pacing back and forth through the application of time-out procedures. The intervention condition was stopped on the eleventh day because the data already showed a stable graph line.

At the baseline condition after intervention (A2), the researcher conducted the re-observations of the child's hyperactivity behavior of pacing back and forth. The data on this second condition were obtained after 4 days of observations, with the duration of 3 minutes, 2 minutes, 2 minutes, and 2 minutes. The observations were stopped at the 15 th meeting.

The components in the inter-conditions analysis are shown in the Table below:

Table 1.The Summary of Inter-conditions Analysis on the Hyperactivity Behaviors of Pacing Back and Forth

\begin{tabular}{|c|c|c|c|}
\hline $\mathbf{N}$ & Condition & A1:B & A2:B \\
\hline 1 & $\begin{array}{l}\text { The number of changed } \\
\text { variables }\end{array}$ & 1 & 1 \\
\hline 2 & $\begin{array}{l}\text { Direction inclination } \\
\text { changes and their effects }\end{array}$ & $(+) \quad(+)$ & $(+){ }^{(+)}$ \\
\hline 3 & $\begin{array}{l}\text { Changes in stability } \\
\text { inclination }\end{array}$ & $\begin{array}{r}\text { Variable } \\
\text { to }\end{array}$ & $\begin{array}{r}\text { Variable } \\
\text { to }\end{array}$ \\
\hline 4 & Level changes & $4-4=$ & $2^{4}$ \\
\hline 5 & Overlapping changes & $0 \%$ & $0 \%$ \\
\hline
\end{tabular}


The observations for all the condition levels both at home and at school were conducted fifteen times. The observations for the baseline condition before treatment (A1) were done six times; the observations for the intervention condition (B) were done five times; meanwhile, the observations for the baseline condition after treatment (A2) were done four times. In this study there was a reduction in the duration of hyperactivity behavior of pacing back and forth after having been treated using the time-out procedure. According to Martin and Pear, a time-out is a procedure that removes a source of reinforcement for a certain period of time, when the objective behavior to be eliminated arises [6].

In this research, the observations in the baseline condition were done six times (from the first meeting to the sixth meeting). The first observation on the child's hyperactivity behavior of pacing back and forth was done with in the duration of 8 minutes. Then, the observations conducted in the second to the sixth meeting were done within the duration of 15 minutes, 19 minutes, 8 minutes, 8 minutes and 8 minutes respectively. Meanwhile, the observations in the intervention condition (B) began in the seventh meeting in which the observation on the child's hyperactivity behavior was done within the duration of 4 minutes. Then, the observations conducted in the eighth to the eleventh meeting were done within the duration of 6 minutes, 5 minutes, 5 minutes, and 5 minutes respectively. In the last condition, baseline condition after intervention (A2), the observations began in the twelfth meeting in which the observation on the child's hyperactivity behavior was done within the duration of 3 minutes. Then, the observations in the thirteenth to fifteenth meeting were done within the duration of 2 minutes, 2 minutes, and 2 minutes. The less duration spent during the baseline condition after intervention (A2) indicates that the child's hyperactivity behavior of pacing back and forth has decreased.

Therefore, it is obviously visible that the results of the baseline condition (A1) indicate the high duration of hyperactivity behavior of pacing back and forth performed by the child with autism, but after having been given a treatment through time-out procedure during intervention condition (B), the hyperactivity behavior performed by the child with autism decreased gradually, and could be maintained at the baseline condition after intervention (A2). Thus, the results of this study have shown that the hyperactivity behavior of pacing back and forth performed by the child with autism can be reduced through the time-out procedure.

\section{CONCLUSION}

The results of the research conducted in SLB Autism YPPA Padang show that the time-out strategy/procedure successfully reduced the hyperactivity behavior of $\mathrm{X}$, the student with autism. The results were obtained from the graphic analysis and careful calculation of the data obtained in the field showing the reduction in the behavior of pacing back and forth performed by X.

\section{References}

L. Kanner et al., "Library of the History of Autism Research,
Behaviorism \& Psychiatry," Nerv. Child, vol. 2, pp. 217-250, 1943.

[2] Y. Handojo, "Autisma," Jakarta PT. Bhuana Ilmu Pop., 2003.

[3] R. Marienzi, "Meningkatkan Kemampuan Mengenal Konsep Angka Melalui Metode Multisensori Bagi Anak Autis," E-JUPEKhu, vol. 1, no. 3, 2012.

[4] B. Danuatmaja and H. Rozaline, Terapi anak autis di rumah. Puspa Swara, 2003.

[5] A. Suharsimi, "Prosedur penelitian suatu pendekatan praktek," Jakarta: Rineka Cipta, 2006.

[6] E. Purwanta, "Modifikasi perilaku," Yogyakarta: Pustaka Pelajar, 2012. 